\title{
Insects in the White Stork Ciconia ciconia Diet as Indicators of ITS FEEDING CONDITIONS: THE FIRST DIET STUDY IN SLOVENIA
}

\section{Žuželke v prehrani bele štorklje Ciconia ciconia kot indikatorji njenih prehranskih razmer: prva raziskava prehrane vrste $\mathbf{v}$ Sloveniji}

\author{
Al VREZEC \\ National Institute of Biology, Večna pot 111, SI-1000 Ljubljana, Slovenia, e-mail: al.vrezec@nib.si
}

\begin{abstract}
Prey remains found in the pellets of the White Stork Ciconia ciconia are known not to reveal the actual prey intake by the White Storks. The exceptions are the chitinous remains of insects that are quite well preserved in the pellets, and thus potentially good indicators of the actual intake of White Storks. Since insects are selected by White Storks in proportion to their abundance in the environment, they can be used as indicators of the quality of the bird foraging habitat. A preliminary test of this was carried out at three nests in NE Slovenia differing in their breeding success in 1997. In contrast to habitat analysis around the nest the proportions of Orthoptera and Coleoptera in the pellets corresponded well to the breeding success. Orthoptera species were dominant in high success, and Coleoptera (especially Carrion beetles Silphidae) in low success nests. In this paper the value of insects in White Stork pellets as indicators of the quality of the bird foraging microhabitat patches is set out. However, the indicative power of these insects needs to be tested further.
\end{abstract}

Key words: White Stork, Ciconia ciconia, diet, Slovenia, insects, indicators Ključne besede: bela štorklja, Ciconia ciconia, prehrana, Slovenija, žuželke, indikatorji

\section{Introduction}

The diet of the White Stork Ciconia ciconia is relatively well known all over its distributional range in Europe (e.g. Pinowska \& Pinowski I985, SackL I987, DZIEWIaTy I992, MuŽINIĆ \& RAŠAJSKi I992, RÉKÁsI 2000, ANTCZAK et al. 2002, TSACHALIDIS \& Goutner 2002). Most diet studies used pellet analysis, although it was established that prey remains found in pellets do not reveal the only prey intake by the Storks (PINOwski et al. I99I, MuŽINIĆ \& RAŠAJSKI 1992). For example, earthworms Lumbricidae and amphibians Amphibia are mostly missing in the pellets since this prey is almost entirely digested, and other vertebrate prey e.g. mammals, birds and fish, are usually underestimated. On the other hand, chitinous remains of insects are quite well preserved in pellets (e.g. Pinowski $e t$ al. I99I), probably resembling well also the actual intake by White Storks. Almost all diet studies in Europe have confirmed that insects are, besides small mammals, the most important prey taken by White Storks, and that their proportion increases towards southern regions (e.g. PINOwski et al. 1986, SACKL 1987, MuŽINIĆ \& RAŠAJSKI 1992, RÉKÁSI 2000, TSACHalidis \& Goutner 20O2).

Food availability strongly influences White Stork breeding success (TrYJANOwSKI \& KuZNIAK 2002, Tortosa et al. 2003, Massemin-Challet et al. 2006), and breeding birds usually actively select areas with higher food abundance (Alonso et al. I99I, JoHst et al. 200I, Tortosa et al. 2002, JerzaK et al. 2006). Since the White Stork is generally not a sit and wait predator, but takes prey while walking (Cramp 1994), invertebrates, i.e. insects, are selected in proportion to their abundance in the environment (SACKL 1987). Therefore a detailed analysis of insect prey in the White Stork pellets could be useful indicator of the White Stork feeding conditions, since insects are usually habitat specific and can reveal what kind and quality of habitat type the White Stork used for foraging. The 
A. VReZeC: Insects in the White Stork Ciconia ciconia diet as indicators of its feeding conditions: the first diet study in Slovenia

above cited references support the suggestion that White Stork forages at the best and most productive habitat patches available in the vicinity of its nest. The quality of foraging habitat can be estimated from the insect prey taken. This preliminary study was aimed to provide more insight into this problem, and to test if the specific insect prey composition in White Stork pellets corresponds to its breeding success better than a general analysis of the habitat surrounding the nest site. This study is also the first report on the White Stork diet from Slovenia.

\section{Study area and methods}

Three White Stork nests were selected in NE Slovenia, where the bulk of the Slovene White Stork population lives (DenaC 200I): (1) Trnovska vas (46 31'13"N , 15 53'13”E), (2) Lovrenc na Dravskem polju ( $\left.46^{\circ} 22^{\prime} 26^{\prime \prime} \mathrm{N}, 15^{\circ} 46^{\prime} 41^{\prime \prime} \mathrm{E}\right),(3)$ Spodnja Gorica $\left(46^{\circ} 25^{\prime} 5^{\prime \prime} \mathrm{N}, 15^{\circ} 41^{\prime} 31^{\prime \prime} \mathrm{E}\right)$. In 1997 the brood size and number of fledged young were determined for each nest, and the breeding success was expressed as the proportion of successfully fledged young.

Table 1: Comparison of breeding success (proportion of fledged young to total number of young), diet composition (summarised data are marked in bold) and structure of surrounding habitat (categorized according to optimality of land-use types as foraging grounds) between three White Stork Ciconia ciconia nests in NE Slovenia in 1997 (+ indicates just the presence of plant material)

Tabela 1: Primerjava gnezditvenega uspeha (delež speljanih mladičev glede na velikost zalege), prehrane (zbirni podatki so označeni z mastnim tiskom) in strukture okoliškega habitata (kategorije so bile določene glede na optimalnost tipov rabe tal kot prehranjevališč) med tremi gnezdi bele štorklje Ciconia ciconia v SV Sloveniji leta 1997 (+ označuje zgolj prisotnost rastlinskega materiala)

\begin{tabular}{|c|c|c|c|c|c|}
\hline & Locality / Lokaliteta & Trnovska vas & $\begin{array}{l}\text { Lovrenc na Dravskem } \\
\text { polju }\end{array}$ & $\begin{array}{l}\text { Spodnja } \\
\text { Gorica }\end{array}$ & $\begin{array}{l}\text { Total/ } \\
\text { Skupno }\end{array}$ \\
\hline \multirow{2}{*}{$\begin{array}{l}\text { Breeding success/ } \\
\text { Gnezditveni } \\
\text { uspeh }\end{array}$} & No. of young / Št. mladičev & 4 & 3 & 3 & IO \\
\hline & $\begin{array}{l}\text { Proportion of fledged young (\%)/ } \\
\text { Delež speljanih mladičev (\%) }\end{array}$ & IOO.O & $33 \cdot 3$ & $33 \cdot 3$ & 60.0 \\
\hline \multirow{24}{*}{$\begin{array}{l}\text { Diet/ } \\
\text { Prehrana (\%) }\end{array}$} & Plantae & + & + & + & + \\
\hline & Talpa europaea & 0.0 & 2.7 & 2.6 & 2.2 \\
\hline & Arvicolidae & 4.2 & 2.7 & 2.6 & 2.9 \\
\hline & Mammalia, indet. & 0.0 & 2.7 & 0.0 & I.5 \\
\hline & Mammalia, total & 4.2 & 8.2 & 5.I & 6.6 \\
\hline & Pisces & 4.2 & 0.0 & 0.0 & 0.7 \\
\hline & Vertebrata, total & 8.3 & 8.2 & 5.1 & $7 \cdot 3$ \\
\hline & Carabus cancellatus & 0.0 & 2.7 & 0.0 & I.5 \\
\hline & Carabus granulatus & 8.3 & 4.I & 0.0 & 3.7 \\
\hline & Carabidae, other / ostalo & 0.0 & 0.0 & $7 \cdot 7$ & 2.2 \\
\hline & Carabidae, total & 8.3 & 6.8 & $7 \cdot 7$ & $7 \cdot 4$ \\
\hline & Nicrophorus sp. & 0.0 & I. 4 & 0.0 & 0.7 \\
\hline & Silphidae, other / ostalo & 0.0 & 3O.I & 28.2 & 24.3 \\
\hline & Silphidae, total & 0.0 & 31.5 & 28.2 & 25.0 \\
\hline & Melolonthinae & 0.0 & 8.2 & I0.3 & $7 \cdot 4$ \\
\hline & Scarabaeidae, other / ostalo & 0.0 & 4.I & 2.6 & 2.9 \\
\hline & Scarabaeidae, total & 0.0 & $\mathrm{I} 2.3$ & $\mathrm{I} 2.8$ & I0.3 \\
\hline & Coleoptera, other / ostalo & I6.7 & 32.9 & 35.9 & 30.9 \\
\hline & Coleoptera, total & 25.0 & 83.6 & 84.6 & 73.5 \\
\hline & Gryllotalpa gryllotalpa & 12.5 & 2.7 & 5.I & 5.1 \\
\hline & Orthoptera, other / ostalo & 54.2 & 5.5 & $5 \cdot \mathrm{I}$ & I4.0 \\
\hline & Orthoptera, total & 66.7 & 8.2 & 10.2 & I9.I \\
\hline & Insecta, total & 91.7 & 91.8 & 94.9 & 92.6 \\
\hline & No. prey items / Št. plena & 24 & 73 & 39 & 136 \\
\hline \multirow{3}{*}{$\begin{array}{l}\text { Surrounding } \\
\text { habitat / Okoliški } \\
\text { habitat }(\%)\end{array}$} & Optimal / Optimalen & 0.6 & 3.5 & 0.5 & I.5 \\
\hline & Suboptimal / Suboptimalen & 67.6 & $87 \cdot 4$ & 77.5 & 77.5 \\
\hline & Unsuitable / Neprimeren & 31.8 & 9.I & 22.0 & 21.0 \\
\hline
\end{tabular}


Table 2: Test of differences between the three nests (TV - Trnovska vas, LDP - Lovrenc na Dravskem polju, SG Spodnja Gorica) of the White Stork Ciconia ciconia in terms of the structure of the surrounding habitat (proportion of optimal, suboptimal and unsuitable foraging habitats) and of the insect part of the diet (ratio of Coleoptera to Orthoptera in the diet)

Tabela 2: Testiranje razlik v strukturi okoliškega habitata (delež optimalnega, suboptimalnega in neprimernega prehranjevalnega habitata) in v razmerju hroščev Coleoptera in kobilic Orthoptera v prehrani bele štorklje Ciconia ciconia med tremi obravnavanimi gnezdi v SV Sloveniji (TV - Trnovska vas, LDP - Lovrenc na Dravskem polju, SG Spodnja Gorica)

\begin{tabular}{lll}
\hline & & $\begin{array}{l}\text { Ratio of Coleoptera } \\
\text { Comparison/ } \\
\text { Primerjava }\end{array}$ \\
& $\begin{array}{l}\text { Surrounding habitat/ } \\
\text { Okoliški habitat } \\
\text { the diet / Razmerje } \\
\text { hroščev in kobilic v } \\
\text { prehrani }\end{array}$ \\
\hline TV : LDP & $\begin{array}{l}\chi^{2}=17.18, \\
\mathrm{p}<0.001\end{array}$ & $\begin{array}{l}\chi^{2}=36.19, \\
\mathrm{p}<0.00001\end{array}$ \\
TV : SG & $\begin{array}{l}\chi^{2}=2.49, \\
\mathrm{~ns}\end{array}$ & $\begin{array}{l}\chi^{2}<0.00001 \\
\chi^{2}=0.09,\end{array}$ \\
LDP : SG & $\chi^{2}=8.04$, & $\mathrm{ns}$ \\
\hline
\end{tabular}

Between 5 and 12 Jul 1997, pellets under each nest were collected at the time of intensive growth of the young. Pellets were examined in the laboratory and prey items were identified using reference books and collections. Only the presence of plant material was recorded while, in animal prey items, we estimated the number of individuals by bone remains (vertebrate prey), mandibles (Orthoptera) or elytron remains (Coleoptera). Analysis of the surrounding habitat was carried out in a circle of 1500 metres radius around the nest, using the Corinne land use map (MKGP 2002) and GIS tool (Arc View 3.1). This is the distance covered by the majority of foraging flights (Alonso et al. I99I), Based on published data (PINOwski et al. i99i, Tsachalidis \& Goutner 2002, Denac 2006a) we classified different land use types into three classes according to their suitability for the White Stork as foraging habitat: (1) optimal (extensive meadows, water bodies), (2) suboptimal (fields, extensive orchards, intensive meadows, bushy areas and areas in succession forest stage), and (3) unsuitable habitat (hop fields, vineyards, intensive orchards, forest and urban areas). In the analysis we made pair comparisons of the proportion of habitat types ( 3 classes) and the proportion of Orthoptera and Coleoptera in the diet ( 2 classes) with the $\chi^{2}$ test, and compared the results with the differences in breeding success between the observed nests.

\section{Results and discussion}

Insects were the most numerous White Stork prey since they constituted more than $90 \%$ of prey items in all three searched nests (Table 1). This was according to expectations since the White Stork population in Slovenia is in the species' southern distributional range in Europe (ARAúJo \& Biber 1997), where the proportion of insect prey in diet is relatively high (MUŽINIĆ \& RAŠAJSKI I992, RÉKÁsI 2000, TSACHALIDIS \& Goutner 2002). The proportion of vertebrate prey was low, but this can be underestimated, for the reasons discussed in the introduction. When comparing the three nests significant differences were found in the habitat structure or optimality around the nest (Table 2). The nest at Lovrenc na Dravskem polju (LDP) had the highest proportion of optimal habitats and the lowest of unsuitable ones, while there was no statistically significant difference between the nests in Trnovska vas (TV) and Spodnja Gorica (SG) - the proportion of optimal foraging habitats in the nest vicinity was low in both. However, there was no correlation with breeding success since it was high at TV and not at LDP (Table 1).

Further, we tested whether the composition of insect prey items from White Stork pellets - which should resemble relatively well the prey species proportions taken by feeding White Storks - corresponded to breeding success. In the more successful nest (TV) Orthoptera species were dominant, while in the less successful nests (LDP, SG) Coleoptera species prevailed significantly (Tables $1 \& 2$ ). Thus the insect prey structure in the diet appears to correspond very well to the actual breeding success of the White Stork. When considering only the beetle prey species, we found that in the less successful nests the most abundant were Carrion beetles Silphidae, otherwise completely absent from the more successful nest. Two possible explanations may account for this in terms of the general ecology of Carrion beetles (КocH 1989): (1) the White Storks were feeding predominantly on carcasses where carrion beetles can be very numerous or (2) that the White Storks used mainly dry areas for foraging, where Carrion beetles are more abundant than Carabid beetles Carabidae, which are also an abundant beetle prey group. We speculate that the higher proportion of Carrion beetles in the diet indicates that White Storks were feeding either in less favourable dry areas or in areas with lower amounts of suitable prey, and were therefore forced to take carrion to a greater extent.

In general White Storks select specific habitats or even microhabitat patches for foraging (Alonso et al. 1991, JoHST et al. 200I), and these can vary in 
A. VReZeC: Insects in the White Stork Ciconia ciconia diet as indicators of its feeding conditions: the first diet study in Slovenia

optimality. However, individual birds have individual foraging strategies influenced for example by competition, quality of individuals or environmental factors (Denac 2006A \& B), and they can also feed quite far away from the nest (JoHST et al. 200I).

It is therefore almost impossible to identify in which way foraging areas influence the breeding success of White Storks. I therefore propose the use of insect prey remains, which are relatively well preserved in the White Stork pellets, as indicators of the quality of foraging microhabitat patches. To estimate the indicator power of insects in the White Stork diet more studies are needed with larger nest samples included.

Acknowledgements: The study was conducted at the ornithologist-research camp in Markovci in 1997, which was led by Borut Štumberger, who also collected pellet material and initiated the study. The pellet analysis was done by the following camp participants: Lojzi Avsenik, Tjaša Gaube, Gregor Godler and Darja Slana. I am also grateful to Dr. Damijan Denac for his encouragement to finish this work, for his valuable comments during manuscript preparation, GIS habitat analysis, and supplementation with key literature.

\section{Povzetek}

$\mathrm{V}$ predhodnih raziskavah je bilo ugotovljeno, da ostanki plena, najdenega $\mathrm{v}$ izbljuvkih bele štorklje Ciconia ciconia, ne odsevajo dejanske strukture plena, kot ga je ptica zaužila. Izjemna so le hitinski ostanki žuželk, ki so v izbljuvkih dobro ohranjeni in naj bi dejansko odsevali tudi število živali, ki jih je štorklja uplenila. Upoštevaje dejstvo, da štorklja pleni žuželke glede na njihovo dejansko številčnost v okolju, bi bilo mogoče uporabiti žuželke kot indikatorje kakovosti prehranjevalnega habitata bele štorklje. To hipotezo smo preliminarno testirali na primeru treh gnezd v SV Sloveniji z različnim gnezditvenim uspehom v letu 1997. V nasprotju z analizo habitata okoli gnezda se je analiza deleža kobilic Orthoptera proti hroščem Coleoptera v izbljuvkih dobro ujemala z ugotovljenim gnezditvenim uspehom preučevanih štorkelj. Kobilice so bile pogostejše v izbljuvkih ob zelo uspešnem gnezdu, hrošči (zlasti mrharji Silphidae) pa v manj uspešnih gnezdih. $\mathrm{V}$ prispevku je na podlagi tega predstavljen pomen žuželk v izbljuvkih bele štorklje kot indikatorjev kakovosti prehranjevalnega mikrohabitata vrste. Za oceno indikatorske moči žuželk pa bi bile potrebne dodatne raziskave $\mathrm{v}$ prihodnosti.

\section{References}

Alonso, J.C., Alonso, J.A. \& Carrascal, L.M. (i99i): Habitat selection by foraging White Storks, Ciconia ciconia, during the breeding season. - Can. J. Zool. 69: 1957-1962.

Antczak, M., Konwerski, S., Grobelny, S. \& Tryjanowski, P. (2002): The Food Composition of Immature and Non-breeding White Storks in Poland. - Waterbirds 25 (4): 424-428.

Araújo, A. \& Biber, O. (I997): White Stork Ciconia ciconia. pp. 58-59 In: Hagemaijer, W. J. M. \& Blair, M. J. (eds.): The EBCC Atlas of European Breeding Birds. T $\&$ AD Poyser, London.

Cramp, S. (ed.) (1994): Handbook of the Birds of Europe, the Middle East and North Africa, The Birds of the Western Palearctic. - Oxford University Press, Oxford, New York.

Denac, D. (200I): Gnezditvena biologija, fenologija in razširjenost bele štorklje Ciconia ciconia v Sloveniji. Acrocephalus 22: 89-103.

Denac, D. (2006A): Resource-dependent weather effect in the reproduction of the White Stork Ciconia ciconia. Ardea 94 (2): 233-240.

Denac, D. (2006B): Intraspecific Exploitation Competition as Cause for Density Dependent Breeding Success in the White Stork. - Waterbirds 29 (3): 391-394.

Dziewiaty, K.(I992): NahrungsökologischeUntersuchungen am Weißstorch Ciconia ciconia in der Dannenberger Elbmarsch (Niedersachsen). - Die Vogelwelt 113: 133144.

Jerzak, L., Bocheński, M. \& Czechowski, P. (2006): Unusual feeding behaviour of the White Stork Ciconia ciconia in the Klopot colony (W Poland). pp. 203-207 In: Tryjanowski, P., Sparks, T.H. \& Jerzak, L. (eds.): The White Stork in Poland: studies in biology, ecology and conservation. - Bogucki Wydawnictwo Naukowe, Poznan.

Johst, K., Brandl, R. \& Pfeifer, R. (200I): Foraging in a patchy and dynamic landscape: human land use and the White Stork. - Ecological Applications 11 (1): 60-69.

Koch, K. (1989): Die Käfer Mitteleuropas, Ökologie, Band 1. - Goecke \& Evers Verlag, Krefeld.

Massemin-Challet, S., Gendner, J.P., Samtmann, S., Pichegru, L., Wulgué, A. \& Le Maho, Y. (2006): The effect of migration strategy and food availability on White Stork Ciconia ciconia breeding success. - Ibis 148: 503-508.

MKGP (2002): Karta dejanske rabe tal. - Ministrstvo za kmetijstvo, gozdarstvo in prehrano, Ljubljana.

MuŽINIĆ, J. \& RAŠAJSKI, J. (I992): On food and feeding habits of the White Stork, Ciconia c. ciconia, in the Central Balkans. - Ökol. Vögel 14: 211-223.

Pinowska, B. \& Pinowski, J. (I985): Feeding ecology and diet of the White Stork Ciconia ciconia in Poland. pp. 381396 In: Rheinwald, G., Ogden, J. \& Schulz, H. (eds.): White Stork, Status and Conservation. Proceedings of the First International Stork Conservation Symposium, Walsrode, 14-19 October 1985. - International Council for Bird Preservation, DDA. 
Pinowski, J., Pinowska, B., de Graaf, R. \& Visser, J. (1986): Der Einflu $\beta$ des Milieus auf die NahrungsEffektivität des Weißstorchs (Ciconia ciconia L.). - Beih. Veröff. Naturschutz 43: 243-252.

Pinowski, J., Pinowska, B., de Graaf, R., Visser, J. \& DziurdzIK, B. (I99I): Influence of feeding habitat on prey capture rate and diet composition of White Stork Ciconia ciconia (L.). - Studia Naturae - seria A, Zaklad ochrony przyrody I, Zasobów naturalnych Polskiej akademii nauk: 59-85.

RÉKÁsI, J. (2000): A study of the White Stork population of North Bácska in 1999. - Ornis Hung. 10: 225-229.

SACKL, P. (1987): Über saisonale und regionale Unterschiede in der Ernährung und Nahrungswahl des Weißstorches (Ciconia c. ciconia) im Verlauf der Brutperiode. - Egretta 30: 49-79.

Tortosa, F.S., Caballero, J.M. \& Reyes-López, J. (2002): Effect of Rubbish Dumps on Breeding Success in the White Stork in Southern Spain. - Waterbirds 25 (1): 39-43.

Tortosa, F.S., Pérez, L. \& Hillström, L. (2003): Effect of food abundance on laying date and clutch size in the White Stork Ciconia ciconia. - Bird Study 50: 112-115.

Tryjanowski, P. \& Kuźniak, S. (2002): Population size and productivity of the White Stork Ciconia ciconia in relation to Common Vole Microtus arvalis density. Ardea 90 (2): 213-217.

Tsachalidis, E.P. \& Goutner, V. (2002): Diet of the White Stork in Greece in Relation to Habitat. - Waterbirds 25 (4): 417-423.

Arrived / Prispelo: 10.6.2008

Accepted / Sprejeto: 5.8.2009 